\title{
Mediated Electrochemical Oxidation of Pollutants in Crude Oil Desalter Effluent
}

\author{
F. García-Lugo ${ }^{1,2}$, A. Medel $^{1, *}$, J.L. Jurado Baizaval ${ }^{1}$, P. Mijaylova Nacheva ${ }^{3}$, \\ A. Durán Moreno ${ }^{2}$, M.J. Cruz Gómez ${ }^{2}$ L. Godínez Mora-Tovar ${ }^{1}$ and Y. Meas ${ }^{1, *}$ \\ ${ }^{1}$ Centro de Investigación y Desarrollo Tecnológico en Electroquímica, S.C., Parque Tecnológico, \\ Querétaro-Sanfandila, P.O. Box 064 - 76703, Pedro Escobedo, Querétaro, México. \\ ${ }^{2}$ Facultad de Química, Universidad Nacional Autónoma de México, Col. Coyoacán- 04510 Ciudad de \\ México, México. \\ ${ }^{3}$ Instituto Mexicano de Tecnología del Agua, Blvd. Paseo Cuauhnáhuac 8532, Colonia Progreso - \\ 62550 Jiutepec, Morelos, México. \\ *E-mail: yunnymeas@ cideteq.mx, amedel@ cideteq.mx
}

doi: $10.20964 / 2018.01 .03$

Received: 12 September 2017 / Accepted: 21 October 2017 / Online Published: 1 December 2017

\begin{abstract}
Wastewater samples from a crude oil desalting process were subjected to extensive physicochemical characterization and electrolysis to evaluate the two main reaction pathways, electrochemical incineration and mediated oxidation, that occur during an electrochemical oxidation process (EOP) with a boron-doped diamond (BDD) anode. The effects of the main operating variables ( $\mathrm{pH}$, current density, and ionic composition) on the oxidation of organic pollutants and the production of hydroxyl radicals $\left({ }^{\bullet} \mathrm{OH}\right)$ were evaluated via spectroelectrochemistry, quantification of the total organic carbon (TOC), and fluorescence spectroscopy. The predominance of each reaction pathway was evaluated using tert-butyl alcohol $(50 \mathrm{mM})$ as a ${ }^{\bullet} \mathrm{OH}$ scavenger, the main oxidant species in electrochemical incineration. The results indicated that the action of ${ }^{\circ} \mathrm{OH}$ was minimal compared to that of active chlorine species $\left(\mathrm{ClO}^{-}, \mathrm{HClO}\right.$, and $\left.\mathrm{Cl}_{2}\right)$, oxychlorine radicals $\left(\mathrm{ClO}^{\bullet}, \mathrm{ClO}_{2}{ }^{\bullet}, \mathrm{Cl}^{\bullet}\right.$, and $\left.\mathrm{HOCl}^{\bullet}\right)$, and oxychlorine anion radicals $\left(\mathrm{Cl}_{2}{ }^{\bullet-}\right.$, and $\left.\mathrm{HOCl}^{\bullet}\right)$. Under the optimal operating conditions $(\mathrm{pH} 8.5, j=$ $100 \mathrm{~mA} \mathrm{~cm}^{-2}$, and $t_{r}=3 \mathrm{~h}$ ), a $98.2 \%$ mineralization rate in terms of TOC was achieved. Mediated electrochemical oxidation was the predominant reaction pathway and was thus responsible for the high degradation efficiency obtained.
\end{abstract}

Keywords: desalter effluent; boron-doped diamond; electrochemical incineration; mediated electrochemical oxidation; active chlorine.

FULL TEXT 
(C) 2018 The Authors. Published by ESG (www.electrochemsci.org). This article is an open access article distributed under the terms and conditions of the Creative Commons Attribution license (http://creativecommons.org/licenses/by/4.0/). 